\title{
Safety Assessment of the Transit Oil- and Gas-Pipelines with Corrosion Pits*
}

\author{
L. Toth and B. G. Lenkey
}

Bay Zoltan Foundation for Applied Research, Miskolc, Hungary

УДК 539.4

\section{Оценка безопасности магистральных нефте- и газопроводов с коррозионными язвами}

\author{
Л. Тот, Б. Г. Ленки
}

Фонд прикладных исследований им. Золтана Бая, Мишкольц, Венгрия

Построеньд диаграммьл надежсности подземньх трубопроводов с коррозионньми дефектами, основанные на конечноэлементном анализе. Численные расчеты выполиялись для дефектов $c$ реальныли геометрическими размерами, а также для трех упроченньх геометрических схем дефектов. Для проверки результатов конечноэлементных расчетов проводились испьтания на разрьєв нескольких участков трубопровода.

Ключевые слова: коррозионная язва, надежность, конечноэлементный расчет, испытания на разрыв.

Introduction. The presently applied engineering methods for reliability assessment of corrosion pits in pipelines are usually conservative. The measure of conservatism strongly depends on the method, if it is based on the yield strength or tensile strength of the pipe material, as well as the applied mechanical model of the defect, as it is demonstrated in Fig. 1 [1-3]. The objective of our work was to investigate the finite element method (FEM) applicability for assessing the failure pressure and to develop less conservative safety diagrams for underground oil pipelines.

1. Applicability of FEM and Simplified Defect Models. First the applicability of simplified defect models was analyzed. For the FEM calculations four different defect models were developed:

(i) real 3D defect geometry determined on the basis of laser scanning of the sample of the real defects, as it is shown in Fig. 2 [1];

(ii) simplified defect with rectangular shape;

(iii) simplified defect with second order surface (parabolic);

(iv) simplified defect with sixth order surface.

The defect models were constructed in the following way: the depth of the defect is equal to the depth of the deepest point of the real defect, the overall

\footnotetext{
* Report on International Scientific Conference "Strength and Reliability of Trunk Pipelines" (MT-2008) (5-7 July, 2008, Kiev, Ukraine).
} 
dimensions of the defect were adjusted to the finite element mesh. The size of the mesh was $3 \mathrm{~mm}$ in order to avoid the large number of elements in the model. The shapes of the simplified defect models are shown in Fig. 3, which were then incorporated into the FEM model of the pipe.

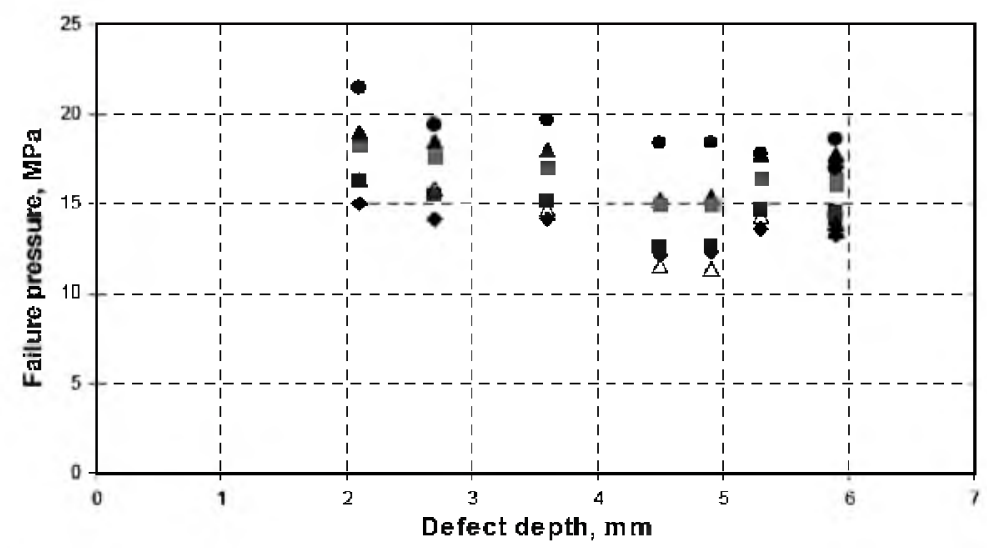

- ASME B31.G a RSTRENG ADNV RP-F 101 abattelle $\triangle$ Shell-92 - Measured

Fig. 1. Comparison of failure pressure of pipelines with corrosion pits assessed using different guidelines.

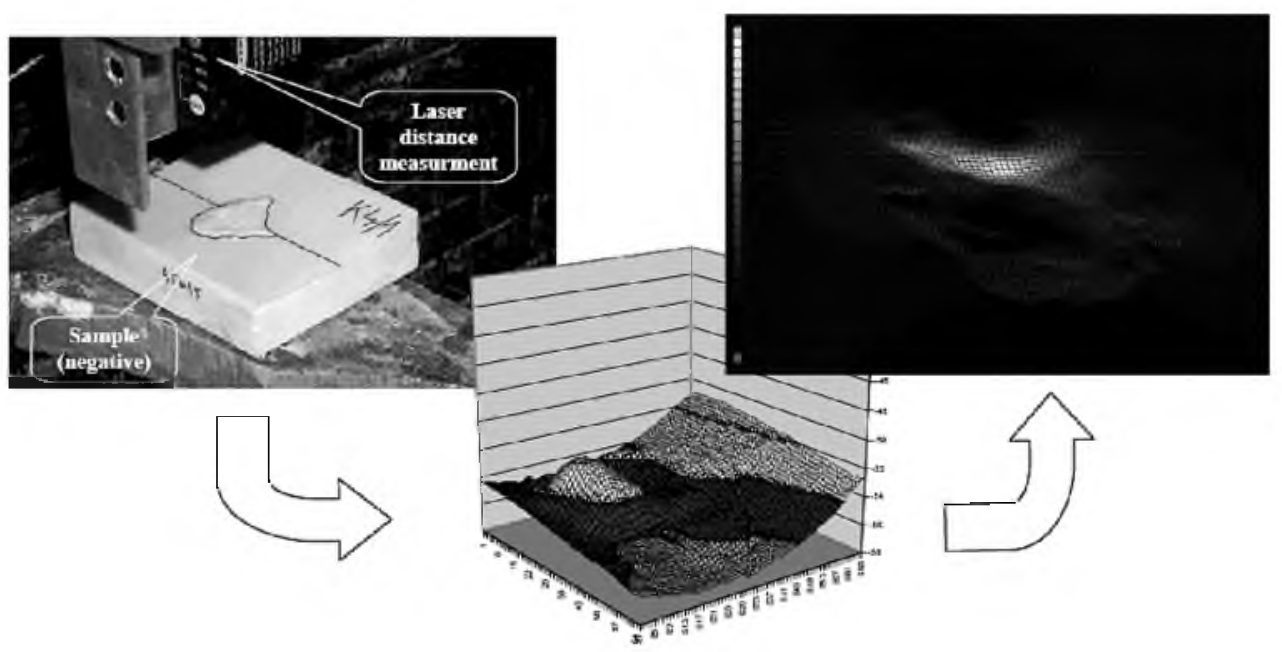

Fig. 2. Method for generation of real 3D defect model.

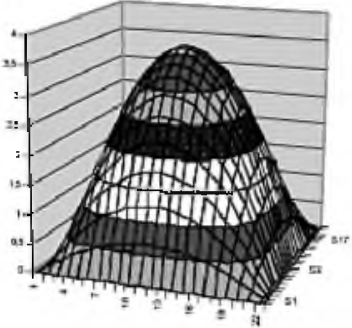

$a$

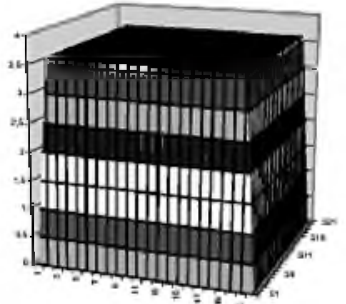

$b$

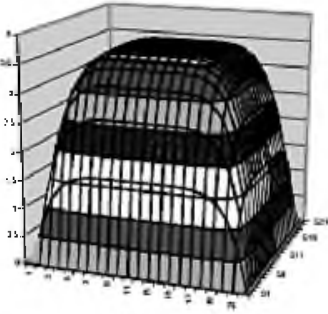

C

Fig. 3. The simplified defect models: $(a)$ parabolic; $(b)$ rectangular; $(c)$ sixth order surface. 
Elastic-plastic finite element analysis have been performed with large deformation option. The material parameters of the pipe used in the first calculations were: $R_{y}=334 \mathrm{MPa}$ (yield strength), $R_{m}=468 \mathrm{MPa}$ (tensile strength). The following failure criterion was used for predicting the failure pressure: the equivalent Mises stress at the deepest point of the defect has reached the true stress value corresponding to the tensile strength (beginning of plastic instability), i.e.,

$$
\sigma_{\text {red }}=R_{m}^{\prime}
$$

The predicted failure pressure values have been compared with burst test results, as it is shown in Fig. 4. Comparison of the results of different defect models showed that the parabolic and the 6th order models gave the best predictions. The predicted failure pressure values using parabolic model were very close to the measured ones, and were conservative in each cases. There was not significant difference between the real defect and the parabolic defect model results.

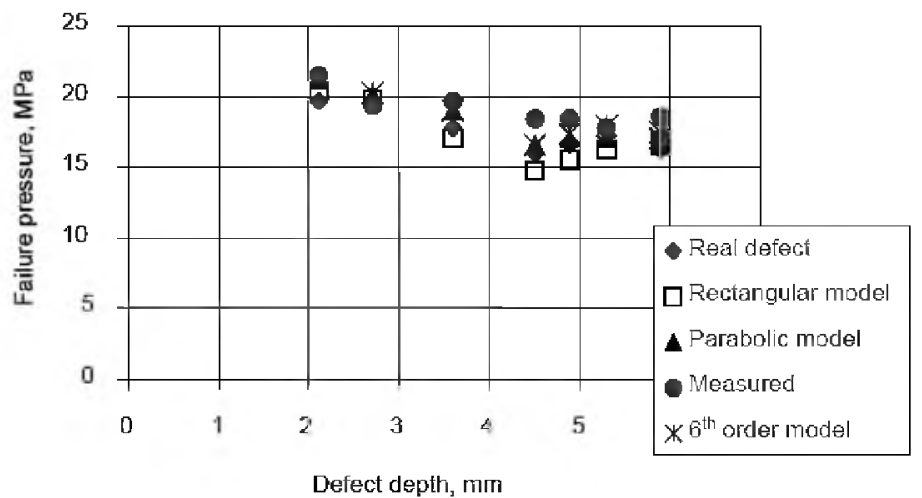

Fig. 4. Failure pressure vs. defect depth: comparison of different defect models and the burst test results.

2. Development of Safety Diagrams. Based on the above results, parabolic model was selected for further calculations with different pipe geometries and materials. This made it possible to elaborate safety diagrams based on large number of FEM calculations with variation of the defect dimensions in a wide range.

Most frequently applied pipeline geometry (diameter, wall thickness) and materials were selected for further calculations that are shown in Table 1. The dimensions of the parabolic defect were varied, and calculations were performed for all possible combinations of these defect sizes, as shown in Table 2.

The equivalent Mises stress values at the deepest point of the defect were evaluated from the FEM calculations as a function of internal pressure. Based on this, three different critical pressure values were determined according to Fig. 5:

1). Pressure at the beginning of plastic deformation at the deepest point of the defect: $P_{y s}$.

2). Pressure at the end of the plastic yield (end of the horizontal section in Fig. 5): $P_{y f}$. 
$\mathrm{T}$ a b 1 e 1

Material and Dimensions of the Investigated Pipelines

\begin{tabular}{|c|c|c|}
\hline Material grade & External diameter $D, \mathrm{~mm}$ & Wall thickness $t, \mathrm{~mm}$ \\
\hline A52K & 323.9 & 5.0 \\
\hline X52 & 323.9 & 6.3 \\
\hline X52 & 406.4 & 5.6 \\
\hline DX60 & 406.4 & 7.1 \\
\hline X52 & 609.6 & 10.0 \\
\hline DX60 & 609.6 & 8.0 \\
\hline DX52 & 406.4 & 7.1 \\
\hline DX52 & 406.4 & 8.0 \\
\hline
\end{tabular}

T a b 1 e 2

Dimensions of the Generated Parabolic Defects

\begin{tabular}{|c|c|c|}
\hline $\begin{array}{c}\text { Defect length (axial) } \\
L, \mathrm{~mm}\end{array}$ & $\begin{array}{c}\text { Defect width (circumferential) } \\
B, \mathrm{~mm}\end{array}$ & $\begin{array}{c}\text { Relative defect depth, } \\
d / t\end{array}$ \\
\hline 12 & 6 & 0.25 \\
\hline 24 & 18 & 0.50 \\
\hline 48 & 42 & 0.62 \\
\hline 150 & 60 & 0.72 \\
\hline 282 & & 0.85 \\
\hline 402 & & \\
\hline 498 & & \\
\hline
\end{tabular}

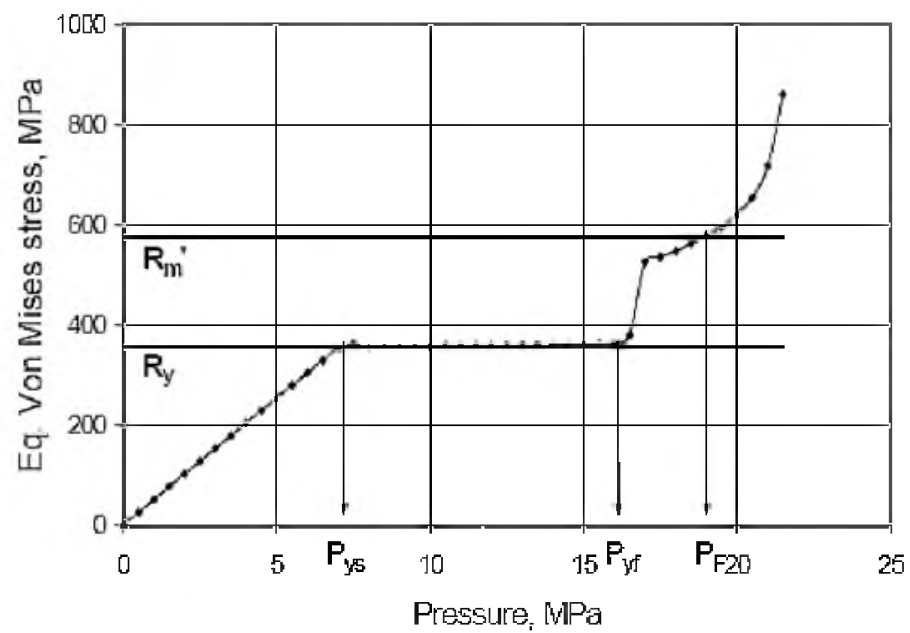

Fig. 5. The equivalent Mises stress vs. internal pressure at the deepest point of the defect determination of critical pressure values. 
3). Pressure at the beginning of plastic collapse - predicted failure pressure: $P_{F}$.

Based on the three critical pressure values, set of safety diagrams could be generated for each of selected pipe diameter and material. In these diagrams, according to the general practice, $L / D$ was put on the horizontal axis. For the vertical axis, the predicted critical pressure and its normalized values could be selected. The predicted failure pressure of a flawless pipe [Eq. (2)] was used for normalization:

$$
P_{F-F L}=2 R_{m}^{\prime} t /(D-t)
$$

where $t$ is wall thickness of the pipe (in $\mathrm{mm}$ ), $D$ is external diameter of the pipe (in $\mathrm{mm}$ ), and $R_{m}^{\prime}$ is true stress belonging to tensile strength (in $\mathrm{MPa}$ ).

The normalized critical pressure values were then calculated according to Eqs. (3)-(6):

$$
\begin{aligned}
& \text { norm }-P_{y s}=P_{y s} / P_{F-F L}, \\
& \text { norm- } P_{y f}=P_{y f} / P_{F-F L}, \\
& \text { norm- } P_{F}=P_{F} / P_{F-F L}, \\
& \text { norm- } P_{o p}=P_{o p} / P_{F-F L},
\end{aligned}
$$

where $P_{o p}$ is the operation pressure.

As an example for the possible representation of the safety diagrams, Fig. 6 shows the normalized critical pressure values for $B=60 \mathrm{~m}$ defect width. Figure 7 shows a set of safety diagrams for different critical pressure values. The points in the diagrams indicate the discrete values where the FEM calculations were performed. Based on these safety diagrams, three different safety factors can be interpreted for the different critical pressure values according to Eqs. (7)-(9):

$$
\begin{aligned}
& n_{1}=P_{y s} / P_{o p}, \\
& n_{2}=P_{y f} / P_{o p}, \\
& n_{3}=P_{F} / p P_{o p} .
\end{aligned}
$$

The main advantage of the developed safety diagrams and the safety assessment method is that not only the safety against the leakage can be evaluated, but also the safety against the beginning of the plastic deformation and plastic instability, thus giving opportunity for the pipeline operator to establish and use a less conservative and more complex assessment criteria for corrosion defects.

The determination of the required safety level is the task and responsibility of the pipeline operator. The minimum required safety factor value may be different for different pipeline sections depending on the consequence of a possible failure, thus a risk based assessment method could be implemented in the every day operational practice. 

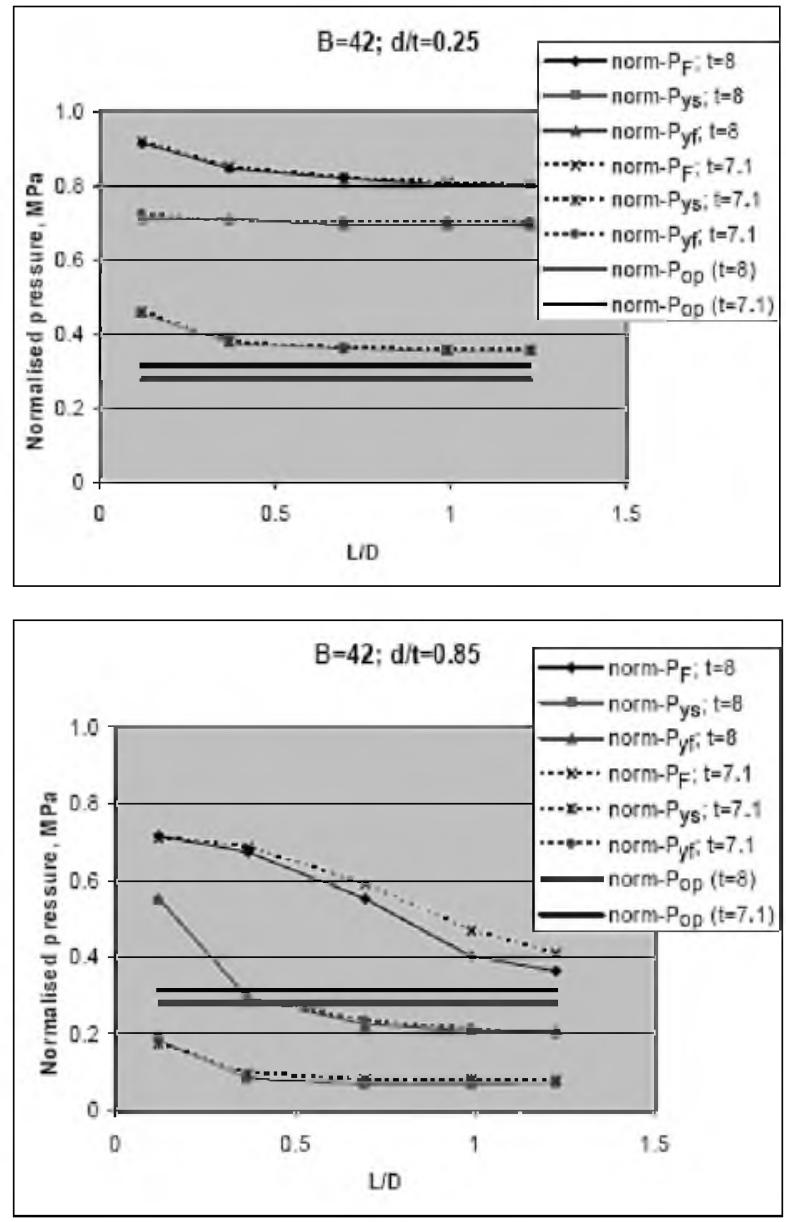

Fig. 6. Safety diagrams for normalized critical pressure values for two different relative defect depths.

\section{Conclusions}

1. The most accurate prediction of the failure pressure was obtained with the application of parabolic and sixth order surface simplified defect models, but all the simplified models delivered conservative results comparing to the burst test results. The calculation using real 3D defect model did not lead to more accurate prediction.

2. Comparing to the engineering methods the finite element modeling delivered more accurate and less conservative prediction of the failure pressure in each case, which proves the applicability of the FEM. This is even of more importance in the case of longer defects, when the presence of a defect can cause larger decrease in the failure pressure.

3. Based on the stress analysis at the deepest point of the defect on the external and internal surface, it is possible to determine a pressure region within which the failure of the pipe is of highest probability.

4. The simplified defect models can be applied for failure pressure prediction, therefore safety diagrams could be determined on the basis of large number of FEM calculations applying simplified defect models. 
A52K; $D=323,9 \mathrm{~mm} ; \mathrm{t}=5 \mathrm{~mm} ; \mathrm{B}=6 \mathrm{~mm}$

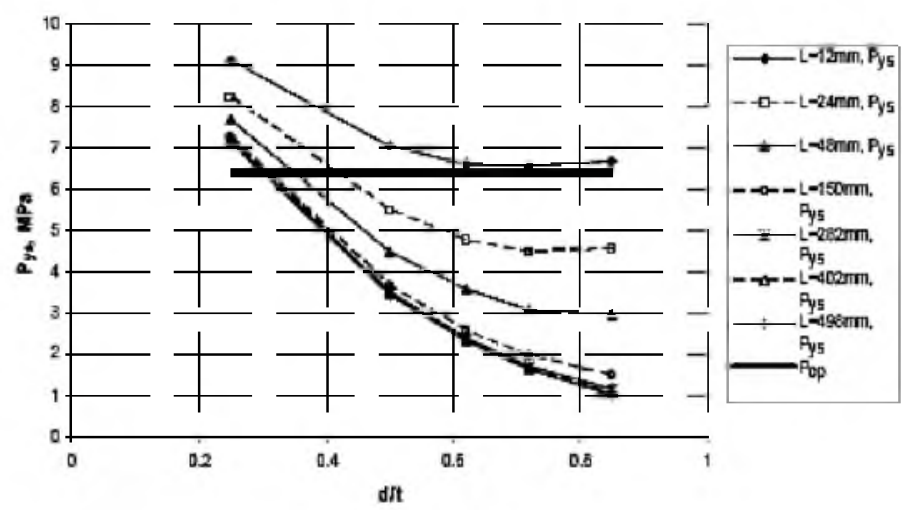

A52K; $D=323,9 \mathrm{~mm} ; \mathrm{t}=5 \mathrm{~mm} ; B=6 \mathrm{~mm}$

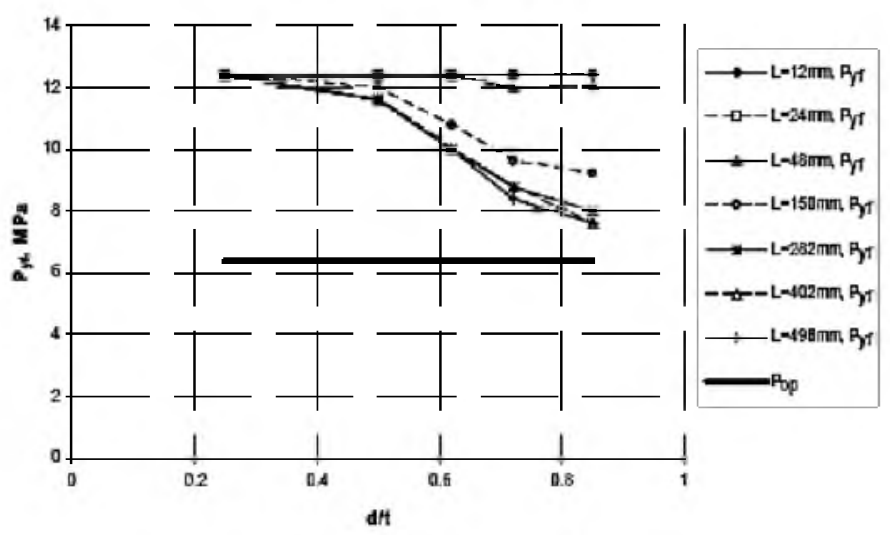

A52K; $D=323,9 \mathrm{~mm} ; \mathrm{t}=5 \mathrm{~mm} ; \mathrm{B}=6 \mathrm{~mm}$
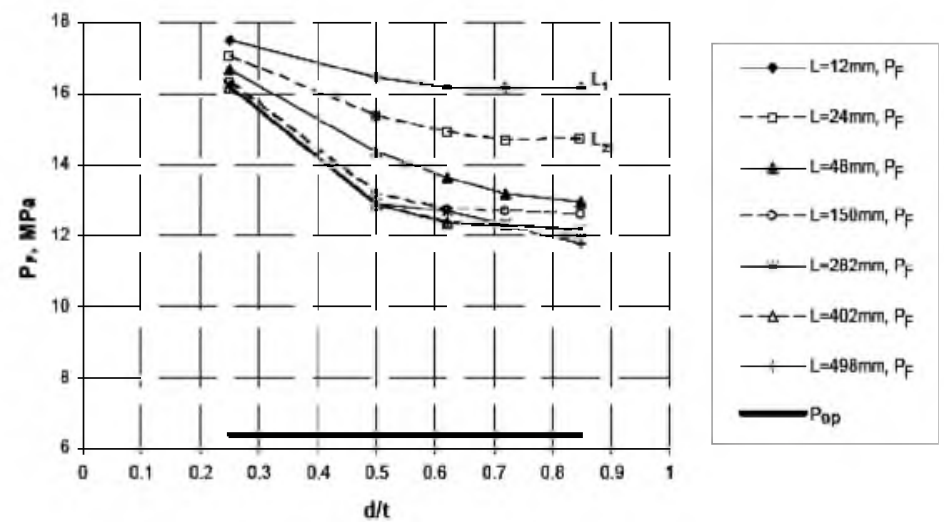

Fig. 7. Safety diagrams for different critical pressure values.

\section{Р ез ом е}

Побудовано діаграми надійності підземних трубопроводів із корозійними дефектами, які базуються на скінченноелементному аналізі. Числові розра- 
хунки виконувалися для дефектів із реальними геометричними розмірами, а також для трьох спрощених геометричних схем дефектів. Для перевірки результатів скінченноелементних розрахунків проводилися випробування на розрив декількох ділянок трубопроводів.

1. B. G. Lenkey, Zs. Balogh, and L. Toth, Assessment of Corrosion Defects in Transit Oil Pipelines using FEM, Internal Research Report (2001-2004).

2. B. G. Lenkey, Zs. Balogh, L. Toth, and I. Harmati, "Reliability assessment of pipelines having corrosion defects using finite element analysis," in: XXV Int. Oil Industry Conf., Balatonfured, Oct. 10-12., 2002 (published on CD).

3. B. G. Lenkey, Zs. Balogh, and L. Toth, "Application of FEM for reliability assessment of corroded pipelines," in: Csopaki Anket, Csopak, Nov. 7-9, 2002.

Received 05. 01. 2009 